\title{
The catastrophic basilar artery occlusion
}

\author{
Wan-Hsiu Liao, ${ }^{1}$ Chih-Cheng Lai, ${ }^{2}$ Shih-Horng Huang, ${ }^{3}$ Sheng-Hsiang Lin ${ }^{4,5}$
}

${ }^{1}$ Department of Family Medicine, New Taipei City Hospital, New Taipei, Taiwan ${ }^{2}$ Department of Intensive Care Medicine, Chi-Mei Medical Center, Liouying, Tainan, Taiwan

Department of Surgery, New Taipei City Hospital, New Taipei, Taiwan

${ }^{4}$ Department of Internal Medicine, New Taipei City Hospital, New Taipei, Taiwan ${ }^{5}$ Department of Respiratory Therapy, Fu-Jen Catholic University, New Taipei, Taiwan

\section{Correspondence to}

Dr Sheng-Hsiang Lin, linsh01@gmail.com
To cite: Liao W-H, Lai C-C, Huang S-H, et al. BMJ Case Rep Published online:

[please include Day Month Yearl doi:10.1136/bcr-2013201004

\section{DESCRIPTION}

A 71-year-old man with hypertension presented to the emergency department with slurred speech, dizziness and four limbs weakness with left side predominance for $3.5 \mathrm{~h}$. A non-contrast CT of head at arrival showed a hyperdense basilar artery (figure 1A) and the diagnosis of basilar artery occlusion (BAO) was made. Given the unavailability of intra-arterial treatment, he received recanalisation therapy with intravenous alteplase $4 \mathrm{~h}$ after the symptom onset; however, a rapid deterioration of consciousness was observed. On the next day, brainstem reflexes were absent and the follow-up CT of head showed extensive infarcts of basilar artery territory and hydrocephalus (figure 1B). The patient received supportive therapy and he passed away 1 week later.

BAO, accounting for about $1 \%$ of all strokes, had been mostly fatal before the introduction of antithrombotic treatment. ${ }^{1}$ Past investigations have demonstrated that early intravenous or intra-arterial thrombolysis has a beneficial effect. ${ }^{1}$ Patients with acute ischaemic stroke would benefit from intravenous tissue plasminogen activator within $4.5 \mathrm{~h}$ after onset, and a shorter time from the onset to treatment is associated with a better outcome. ${ }^{2}$ Likewise, intra-arterial thrombolysis within $6 \mathrm{~h}$ would bring a more favourable outcome for BAO and the prognosis is always dismal beyond $9 \mathrm{~h}^{3}$ The hyperdense basilar artery sign is specific for $\mathrm{BAO}$; nonetheless, it is observed in about two-thirds of patients. $^{1}$ In addition, diffusion-weighted MRI could detect early ischaemic damage of BAO. ${ }^{1}$ Unfortunately, a substantial proportion of patients with BAO died or became dependent despite the endeavours in early diagnosis and modern antithrombotics. ${ }^{1}$ 


\section{Learning points}

- The hyperdense basilar artery sign is a specific CT finding for basilar artery occlusion (BAO), and diffusion-weighted MRI should be performed in patients with diagnostic uncertainty.

- Recanalisation therapy for BAO could be performed by intravenous or intra-arterial thrombolysis, and the time from onset to treatment is crucial.

- The efforts in early diagnosis and recanalisation therapy improve the outcome of $\mathrm{BAO}$; however, $\mathrm{BAO}$ is still a catastrophe for many patients.
Contributors All the authors have contributed in preparing the manuscript, writing the case report, taking decision regarding publication.

Competing interests None.

Patient consent Obtained.

Provenance and peer review Not commissioned; externally peer reviewed.

\section{REFERENCES}

1 Mattle HP, Arnold M, Lindsberg PJ, et al. Basilar artery occlusion. Lancet Neurol 2011;10:1002-14.

2 Saver IL, Fonarow GC, Smith EE, et al. Time to treatment with intravenous tissue plasminogen activator and outcome from acute ischemic stroke. JAMA 2013;309:2480-8.

3 Vergouwen MD, Algra A, Pfefferkorn T, et al. Time is brain (stem) in basilar artery occlusion. Stroke 2012;43:3003-6.

Copyright 2013 BMJ Publishing Group. All rights reserved. For permission to reuse any of this content visit http://group.bmj.com/group/rights-licensing/permissions.

BMJ Case Report Fellows may re-use this article for personal use and teaching without any further permission.

Become a Fellow of BMJ Case Reports today and you can:

- Submit as many cases as you like

- Enjoy fast sympathetic peer review and rapid publication of accepted articles

- Access all the published articles

- Re-use any of the published material for personal use and teaching without further permission

For information on Institutional Fellowships contact consortiasales@bmjgroup.com

Visit casereports.bmj.com for more articles like this and to become a Fellow 